Floresta e Ambiente 2020; 27(1): e20171170

https://doi.org/10.1590/2179-8087.117017

ISSN 2179-8087 (online)

ORIGINAL ARTICLE - Silviculture

Floresta e Ambiente

\title{
Sucrose and substrates on the acclimatization of micropropagated Luehea divaricata plants
}

Karol Buuron da Silva ${ }^{1}$ (1) 0000-0003-2174-2663

Lia Rejane Silveira Reiniger ${ }^{1}$ (1) 0000-0002-3243-671X

Charlene Moro Stefanel ${ }^{1}$ (1) 0000-0002-3173-8150

Silvia Machado dos Santos Rabaiolli ${ }^{1}$ (1) 0000-0003-1331-8803

\begin{abstract}
The objective of this study was to evaluate the effect of sucrose and substrates on the acclimatization of micropropagated Luehea divaricata plants. First, the effect of sucrose on in vitro growth and development of nodal segments in Woody Plant Medium reduced to its half concentration was tested. After that, these shoots were then acclimatized and the combined effect of sucrose, as previously described, plus the commercial substrates vermiculite, MecPlant ${ }^{\oplus}$ or $\mathrm{H}^{-d_{e c k e r}}{ }^{\circ}$ were tested. In the in vitro culture, root and leaf formation were superior (44\%, 8.44 leaves) with $20 \mathrm{~g} \mathrm{~L}^{-1}$ sucrose,

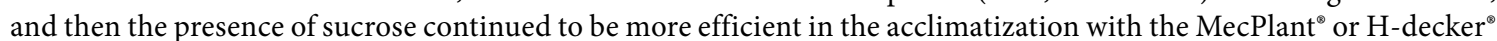
commercial substrates. Sucrose at $20 \mathrm{~g} \mathrm{~L}^{-1}$ is more efficient for in vitro leaf and root formation, and the MecPlant ${ }^{\circ}$ or H-decker ${ }^{\circledast}$ substrates may be used in acclimatization.
\end{abstract}

Keywords: micropropagation, forest species, carbohydrate.

\section{INTRODUCTION AND OBJECTIVES}

Luehea divaricata Martius et Zuccarini, popularly known as açoita-cavalo, is a native species of the Atlantic Rainforest biome, widely used for landscaping, making furniture and recovering degraded areas. In the State of Rio Grande do Sul in Brazil, exploration of the species has been predatory, drastically reducing the specimens with desirable phenotypic characteristics, and contributing to reducing their natural populations. With this reduction, it has been difficult to find seeds of the species, since its viability is irregular. Some studies have already shown that when sown 60 days after harvesting, it germinated $50 \%$ less than when sown immediately after collection. In addition, seed germination can also be considered slow and with moderate rates, varying between $20 \%$ and $75 \%$, which hampers the seminal propagation of the species (Carvalho, 2003; Lorenzi, 2008).

Another fact that may hinder the development of Luehea divaricata seedlings produced by seeds is the batch quality available. Although these propagules come from known matrices with favorable phenotypic characteristics, there is great difficulty in obtaining good quality seeds, with adequate viability and low contamination by microorganisms (Grattapaglia \& Machado, 1998). In view of this, the micropropagation of this species becomes a viable alternative for producing high quality seedlings, thus providing the formation of healthy populations for use in restauration projects in degraded areas.

However, the survival and establishment of micropropagated plants after their removal from their culture room encounter difficulties among woody species, since this transfer can lead to plant stress or even death (Bandeira et al., 2007). In order to minimize the damage caused by the transition from one condition to the other, a pre-adaptation to the autotrophic condition can be performed by reducing the sucrose concentration in the nutritive medium to promote in vitro acclimatization in order to increase the photosynthetic capacity of the plants (Fernandes et al., 2011). Plants do not develop photoautotrophic capacity in the presence of sugar, which can lead to reduced growth and consequent death of the seedlings during the acclimatization phase. However, it is suggested to increase the sucrose level in the phase prior to acclimatization, since this preconditioning would cause an increase in the carbohydrate reserves stored by the leaves, thereby increasing the energy available to the plants during

\footnotetext{
${ }^{1}$ Universidade Federal de Santa Maria (UFSM), Santa Maria, RS, Brasil
} 
the acclimatization process (Grattapaglia \& Machado, 1998; Kozai, 1991).

In the acclimatization phase, plants must be exposed to reduced air humidity and an unstable temperature so that they can adapt and support their transference to the new environment and subsequently survive and develop without complications under field conditions. Thus, the transfer of in vitro conditions to the growth in the external environment must be carried out in a gradual and careful way to avoid damage to the micropropagated plants (Oliveira et al., 2013).

The carbohydrate concentration used in the nutritive medium may vary according to the micropropagation stage, but it is generally maintained between 20 and $30 \mathrm{~g} \mathrm{~L}^{-1}$ (Grattapaglia \& Machado, 1998; Souza \& Pereira, 2007). Sucrose is a non-reducing sugar because its ketone and aldehyde groups are reduced in the form of alcohol, or these groups are combined with a similar group of another sugar, so sucrose is less reactive than reducing sugars (Carvalho et al., 2013). For this reason, sucrose is a highly translocatable sugar (Taiz et al., 2004), which makes it highly efficient for its use in in vitro culture. The sucrose concentration in the nutritive medium has an effect on multiplication and growth, and when it is very high it can lead to problems of excessive osmotic potential, promoting in vitro cultures deterioration. On the other hand, low concentrations can lead to chlorosis in the leaves (Grattapaglia \& Machado, 1998; Lemes et al., 2016).

The acclimatization is also influenced by the substrate used, which may facilitate or impede seedling growth according to their physicochemical properties. The material used as substrate must be inert, porous, well-drained, and able to maintain aeration and humidity, thus allowing root system development (Girardi \& Pescador, 2010; Hoffmann et al., 2001; Vasconcelos et al., 2015). While the substrate may be formed of a single material, it will be difficult to find one able to provide all the necessary characteristics, and for this reason substrates generally represent the blending of two or more materials to optimize usage conditions. In addition, alternative substrates have been tested in rhizogenesis such as vermiculite, aiming at forming a more appropriate root system for adapting the plant in a greenhouse (Curti \& Reiniger, 2014; Oliveira et al., 2013; Schuch \& Damiani, 2009). Thus, this study aimed to evaluate the effect of sucrose and substrates on in vitro and ex vitro acclimatization of Luehea divaricata plants.

\section{MATERIALS AND METHODS}

The tests were carried out at the laboratories and support structures of the Nucleus of Biotechnology and Plant Breeding of the Crop Science Department, Rural Science Center at the Federal University of Santa Maria (UFSM), in Santa Maria, RS, Brazil.

The design used in this experiment and the subsequent acclimatization stages were randomized blocks, testing different concentrations of sucrose $\left(0,10,20\right.$ or $\left.30 \mathrm{~g} \mathrm{~L}^{-1}\right)$ added to the Woody Plant Medium (WPM) nutritive medium (Lloyd \& McCown, 1980) reduced to half of its initial concentration (WPM/2), totaling four treatments. Nine replicates per treatment were used, each consisting of a vial with a volume of $150 \mathrm{~mL}$ filled with $30 \mathrm{~mL}$ of nutritive medium, containing three nodal segments of approximately $6 \mathrm{~mm}$, isolated from plants grown for 60 days in MS (Murashige \& Skoog, 1962) nutritive medium in the absence of growth regulators, and from in vitro germinated seeds. The MS medium used in this germination stage had its conditions established in previous trials, and it was added with $100 \mathrm{mg} \mathrm{L}^{-1}$ myo-inositol, $7 \mathrm{~g} \mathrm{~L}^{-1}$ agar and $30 \mathrm{~g} \mathrm{~L}^{-1}$ sucrose. The seeds were collected from eight trees in a collection conducted in August 2012 in the Ijuí microregion, which were stored in Kraft paper bags for a period of four years in a refrigerator $\left(8-10^{\circ} \mathrm{C}\right)$. Seed disinfestation was also established in previous trials and was performed by the following procedure: immersion of the seeds in hot water $60 \pm 5{ }^{\circ} \mathrm{C}$ for 10 minutes; immersion in $70 \%$ ethanol for one minute, followed by triple rinsing with distilled water and autoclaved; immersion in 3\% sodium hypochlorite solution for $10 \mathrm{~min}$, followed by triple rinsing with distilled water and autoclaved; immersion in $2 \%$ calcium hypochlorite solution for 10 minutes, followed by triple rinsing with distilled water and autoclaved.

The WPM/2 nutritive medium was supplemented with $50 \mathrm{mg} \mathrm{L}^{-1}$ myo-inositol, $7 \mathrm{~g} \mathrm{~L}^{-1}$ agar (Vetec ${ }^{\mathrm{m}}$ ), sucrose according to the treatment, $\mathrm{pH}$ adjusted to 5.8 before inclusion of the agar, and the flasks were subsequently autoclaved for $15 \mathrm{~min}$ at $121^{\circ} \mathrm{C}$ and $1 \mathrm{~atm}$. The explants with approximately $6 \mathrm{~mm}$ were inoculated in a laminar flow chamber and kept in a culture room with a temperature of $25 \pm 3^{\circ} \mathrm{C}$, a photoperiod of $16 \mathrm{~h}$ and luminous intensity of $20 \mu \mathrm{mol} \mathrm{m} \mathrm{m}^{-2} \mathrm{~s}^{-2}$ provided by cool-white fluorescent daylight lamps. After 30 days of in vitro culture, the following variables were evaluated: survival (explants with green coloration), establishment (explants that had any aspect of development), explants with primary and secondary roots expressed in percentage, and number of leaves.

\subsection{First acclimatization period, in vitro (five days in the culture room, with covered plastic cups)}

The plants used in this first period of in vitro acclimatization came from the in vitro culture stage described above, and after 30 days they were transferred to plastic cups containing 
H-decker or MecPlant fine granulometric vermiculite substrate. Plastic cups with $180 \mathrm{~mL}$ capacity were used at this stage of the experiment in which the substrate was added according to the treatment. After transferring 104 sample units, the cups were covered by others of equal capacity, both previously drilled in the base to facilitate substrate drainage and to allow gas exchanges between the external environment and the microclimate created inside the cups.

The plants were then distributed in plastic trays containing a $10 \mathrm{~mm}$ distilled water slide at their base. The trays were placed in a culture room at a temperature of $25 \pm 3^{\circ} \mathrm{C}$, photoperiod of $16 \mathrm{~h}$ with light intensity of $20 \mu \mathrm{mol} \mathrm{m} \mathrm{m}^{-2} \mathrm{~s}^{-1}$ supplied by cool-white fluorescent daylight lamps. The moisture inside the cups was checked every day, and $10 \mathrm{ml}$ of distilled water was added to maintain the plants' water turgor pressure when necessary. The plants remained in these conditions for a period of five days. Survival and establishment (expressed as percentage), plant height $(\mathrm{cm})$ and number of leaves were then evaluated.

\subsection{Second acclimatization period, in vitro (five days in the culture room, with uncovered plastic cups)}

After five days with the covered cups, they were removed, then the plants remained in the culture room for another five days. The moisture inside the cups was checked every day, and $10 \mathrm{ml}$ of distilled water was added to maintain the plants' water turgor pressure when necessary. Eighty-five sample units remained at this stage of the experiment, in which the survival and establishment (expressed as a percentage), plant height $(\mathrm{cm})$ and number of leaves were then evaluated after the five days.

\subsection{Third acclimatization period, ex vitro (30 days in a greenhouse)}

After the first 10 days of acclimatization, the plants were transferred to a greenhouse under controlled temperature $\left(25 \pm 3{ }^{\circ} \mathrm{C}\right)$ and humidity conditions (UR $\left.=80 \%\right)$, where they remained for another 30 days. Sixty sample units were used at this stage of the experiment, in which survival, establishment, primary and secondary root formation (expressed as a percentage), plant height $(\mathrm{cm})$ and number of leaves were evaluated.

\subsection{Statistical analyses}

After testing the normality of the errors by the KolmogorovSmirnov test and the homogeneity of variances by the
Bartlett's test, the means were transformed by the function $\sqrt{x+0.5}$ whenever necessary, where $x$ is the observed value. They were subsequently submitted to analysis of variance, and the means (when the $\mathrm{F}$ value was significant) were compared by the Tukey test for qualitative treatments and polynomial regression analysis for the quantitative treatments at the 5\% error probability level. The precision of the tests was estimated by the index of variation (IV) (Pimentel-Gomes, 2009), also Sisvar (Variance Analysis System) for Windows ${ }^{\circledR}$ version 5.1 was used (Ferreira, 2014).

\section{RESULTS AND DISCUSSION}

At day 30 of in vitro culture there was no significant effect of sucrose concentrations for survival $(p=0.4055$, $\mathrm{IV}=2.37)$ and establishment $(p=0.1645, \mathrm{IV}=3.68)$, with high general averages of $97 \%$ and $81.27 \%$ being observed respectively. Likewise, there was no significant effect of the main factor for secondary root formation $(p=0.2004, \mathrm{IV}=3.55)$, with a general mean of only $6.41 \%$ being obtained.

There was a significant effect of sucrose for the primary root formation $(p=0.0017, \mathrm{IV}=4.17)$ and number of leaves $(p=0.0297 ; \mathrm{IV}=7.03)$, with a second-degree equation being adjusted with the maximum technical efficiency (MTE) estimated at $26.4 \mathrm{~g} \mathrm{~L}^{-1}$ for the first variable, and $20.9 \mathrm{~g} \mathrm{~L}^{-1}$ for the second (Figure 1).

After 30 days of in vitro culture, the primary root formation with $20 \mathrm{~g} \mathrm{~L}^{-1}$ of sucrose was $44 \%$, while with $30 \mathrm{~g} \mathrm{~L}^{-1}$ it was $44.1 \%$ (Figure 1), which enables reducing the amount of sucrose in the nutritive medium with no rooting losses. In addition, this reduction may aid in the subsequent acclimatization of rooted sprouts during in vitro culture, as observed in the third acclimatization period. This occurs because the reduction in the sucrose concentration in the nutritive medium can increase the photosynthetic capacity of the plant, contributing to success in the acclimatization stage (Kozai, 1991).

Similarly, $20 \mathrm{~g} \mathrm{~L}^{-1}$ of sucrose was higher for the number of leaves per shoot, providing an average of 8.44 , while $30 \mathrm{~g} \mathrm{~L}^{-1}$ evidenced the formation of 7.22 at day 30 of in vitro culture (Figure 1). Sucrose in the nutritive medium plays a major role in ensuring the growth and development of plants on the in vitro environment. This source of energy satisfies the carbohydrate requirements, providing both the initial survival of the explant and its subsequent establishment with the formation of new shoots, roots or leaves (Galdiano et al., 2013). 

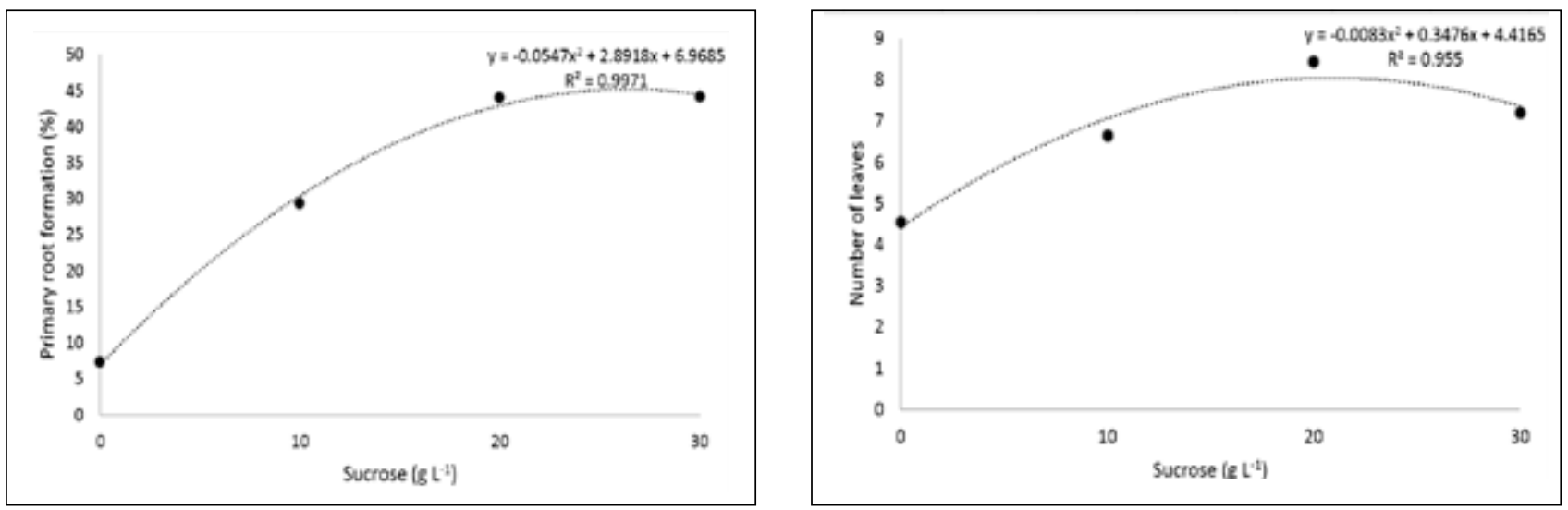

Figure 1. Means of primary root formation (\%) and number of leaves in Luehea divaricata Mart. \& Zucc. shoots, depending on sucrose concentrations after 30 days of in vitro culture in WPM/2 nutritive medium. Santa Maria, RS, UFSM, 2017.

\subsection{First acclimatization period, in vitro (five days in the culture room, with covered plastic cups)}

For survival (IV = 2.75), in the first acclimatization period, there was no significant effect of sucrose concentrations $(p=0.1191)$, the substrate $(p=0.7779)$ and the interaction between the two factors $(p=0.9582)$ resulted in an overall mean of $96.29 \%$. The high average survival in this first period may have been favored by allocating the plants in trays with a water slide at their base, which avoided moisture losses in the substrates. In addition, this step contributed to alleviate the problems that may arise in transferring the flasks, in which there is $100 \%$ humidity for a culture in substrate with limited moisture availability, even if still in the culture room environment.

There was a significant effect of the sucrose concentrations $(p=0.0139)$ (Figure 2), but not of the substrate $(p=0.6425)$ or of the interaction between the main factors $(p=0.7188)$ for the establishment (IV = 5.83), with a second-degree equation being adjusted for this variable with the MTE estimated at $28.9 \mathrm{~g} \mathrm{~L}^{-1}$. There was a significant sucrose effect ( $p=0.0329, p=0.0028$ respectively) for the height (IV $=5.23)$ and number of leaves (IV = 11.48), with a second-degree equation being adjusted for both variables with MTE estimated at $42 \mathrm{~g} \mathrm{~L}^{-1}$ and $23.71 \mathrm{~g} \mathrm{~L}^{-1}$, respectively (Figure 2). There was also a significant effect of the substrate ( $p=0.0323 ; p=0.0059$, respectively) (Table 1 ) for these two variables, but there was no interaction between them ( $p=0.2998, p=0.1378$, respectively).

The presence of sucrose in the nutritive medium positively contributed to the establishment, increase in height and leaf formation in the plants in this first acclimatization stage. Sucrose levels on in vitro culture influence various metabolic processes in the plants, influencing tissue growth and differentiation. The increase in the sucrose concentration generally stimulates the growth and root formation in some species, but only up to a certain concentration; after that it begins to decrease following a quadratic effect (Oliveira et al., 2010). However, other studies carried out in the rooting phase have demonstrated that reducing the sucrose concentration in the nutritive medium is beneficial for improving the root system quality, as well as for the survival of the transplanted plants; this means that the increase or decrease in the carbohydrate concentration, or even their elimination can be decisive in the success of acclimatization (Fernandes et al., 2011; Maldaner et al., 2007).

The composition and consequently the characteristics of the substrates promoted different responses in the shoots, as happened in this work in which the MecPlant ${ }^{\bullet}$ and $\mathrm{H}$-decker ${ }^{\circledR}$ substrates were more favorable than vermiculite in increasing the height and the number of leaves, probably because the first two store more water and air to make available to the plants. One of the most important factors in the development and rooting of shoots is the type of substrate, which must have good water and air retention (Hoffmann et al., 2001; Oliveira et al., 2013). 

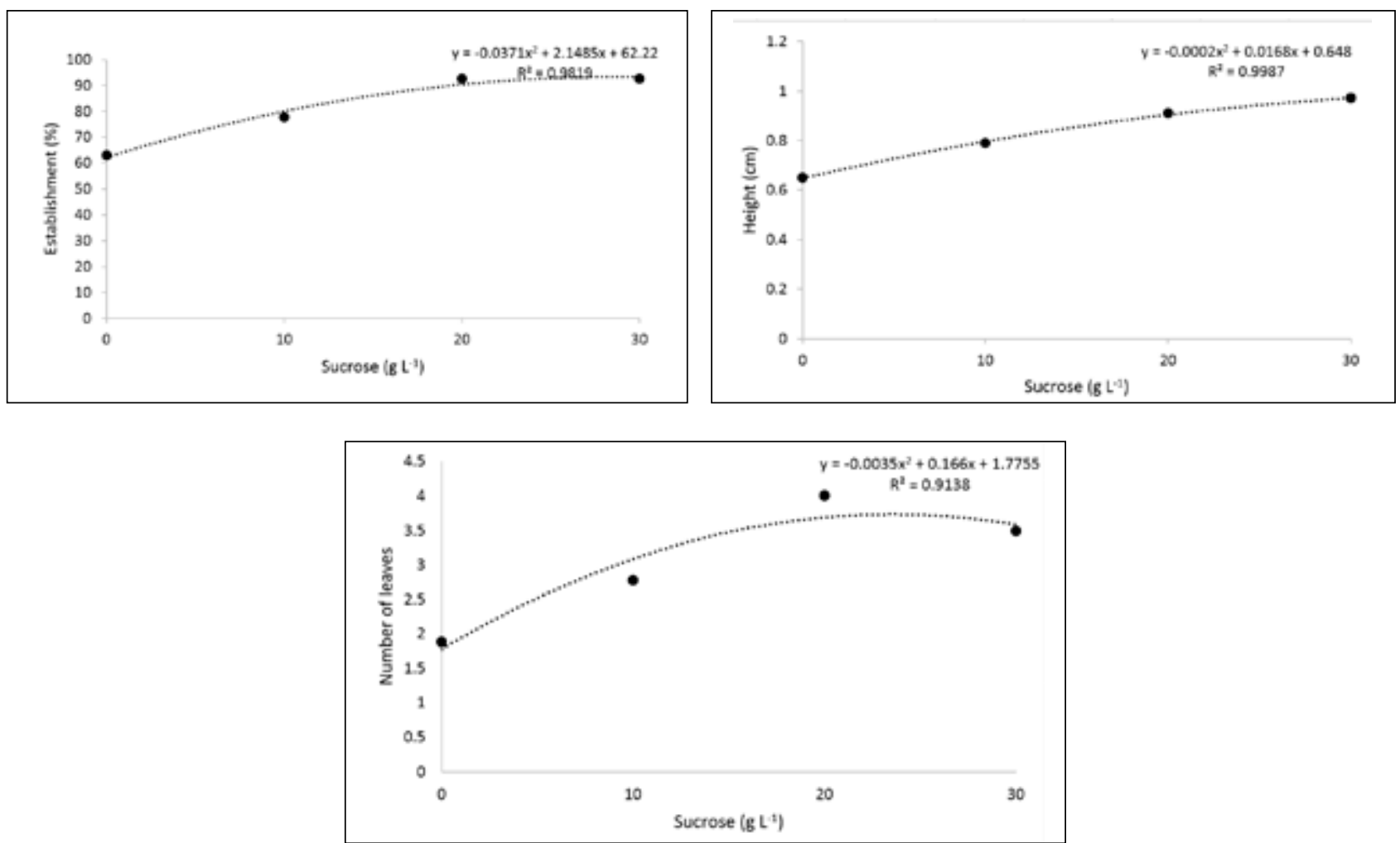

Figure 2. Means of establishment (\%), height $(\mathrm{cm})$ and number of leaves in Luehea divaricata Mart. \& Zucc. shoots, depending on the sucrose concentration used during in vitro culture (30 days) in WPM/2 nutritive medium, regardless of the substrate used later in the first acclimatization period after five days in the culture room with the plastic cups covered. Santa Maria, RS, UFSM, 2017.

Table 1. Means of height (cm), number of leaves and secondary root (\%) in Luehea divaricata Mart. \& Zucc. shoots, depending on the substrate used later in the first, second and third acclimatization period, regardless of the sucrose concentration used during in vitro culture (30 days) in WPM/2 nutritive medium. Santa Maria, RS, UFSM, 2017.

\begin{tabular}{lcccccccc} 
& \multicolumn{2}{c}{ First period } & \multicolumn{2}{c}{ Second period } & \multicolumn{2}{c}{ Third period } \\
\cline { 2 - 8 } \multicolumn{1}{c}{ Substrate } & Height $(\mathbf{c m})$ & $\begin{array}{c}\text { Number of } \\
\text { leaves }\end{array}$ & Height $(\mathbf{c m})$ & $\begin{array}{c}\text { Number of } \\
\text { leaves }\end{array}$ & $\begin{array}{c}\text { Height } \\
(\mathbf{c m})\end{array}$ & $\begin{array}{c}\text { Number of } \\
\text { leaves }\end{array}$ & $\begin{array}{c}\text { Secondary } \\
\text { root }(\%)\end{array}$ \\
\hline Vermiculite & $0.69 \mathrm{~b}^{*}$ & $2.25 \mathrm{~b}$ & $0.55 \mathrm{~b}$ & $2.0 \mathrm{~b}$ & $0.59 \mathrm{~b}$ & $2.02 \mathrm{~b}$ & $11.11 \mathrm{~b}$ \\
\hline H-decker & $0.84 \mathrm{ab}$ & $2.97 \mathrm{ab}$ & $0.75 \mathrm{ab}$ & $2.86 \mathrm{~b}$ & $1.13 \mathrm{ab}$ & $3.52 \mathrm{ab}$ & $44.44 \mathrm{a}$ \\
\hline MecPlant & $0.96 \mathrm{a}$ & $3.88 \mathrm{a}$ & $0.91 \mathrm{a}$ & $3.96 \mathrm{a}$ & $1.29 \mathrm{a}$ & $4.52 \mathrm{a}$ & $52.77 \mathrm{a}$ \\
Mean & 0.83 & 3.03 & 0.73 & 2.94 & 1.00 & 3.35 & 36.10 \\
\hline $\mathrm{IV}^{* *}$ & 5.23 & 11.48 & 8.18 & 15.39 & 15.71 & 23.92 & 11.07 \\
\hline
\end{tabular}

${ }^{*}$ : Means followed by the same letter in the columns do not differ significantly by the Tukey test at $5 \%$ error probability level; ${ }^{* *}$ : Index of variation (IV), calculated by $\mathrm{CV} / \sqrt{\mathrm{N}}$, where IV is equal to coefficient of variation $(\mathrm{CV})$ divided by the square root of the number of repetitions $(\mathrm{N})$.

\subsection{Second acclimatization period, in vitro (10 days in the culture room, with uncovered plastic cups)}

In relation to the second acclimatization period, there was a significant effect of the different sucrose concentrations
( $p=0.0012, p=0.0010$, respectively) (Figure 3), but not of the substrate ( $p=0.7961, p=0.2684$, respectively), nor of the interaction between the two main factors $(p=0.5435, p=0.4273$, respectively) for survival (IV = 7.12) and establishment (IV = 7.94). A second-degree equation was adjusted for both variables, with the MTE estimated at $29.8 \mathrm{~g} \mathrm{~L}^{-1}$ and $26.1 \mathrm{~g} \mathrm{~L}^{-1}$, respectively. 

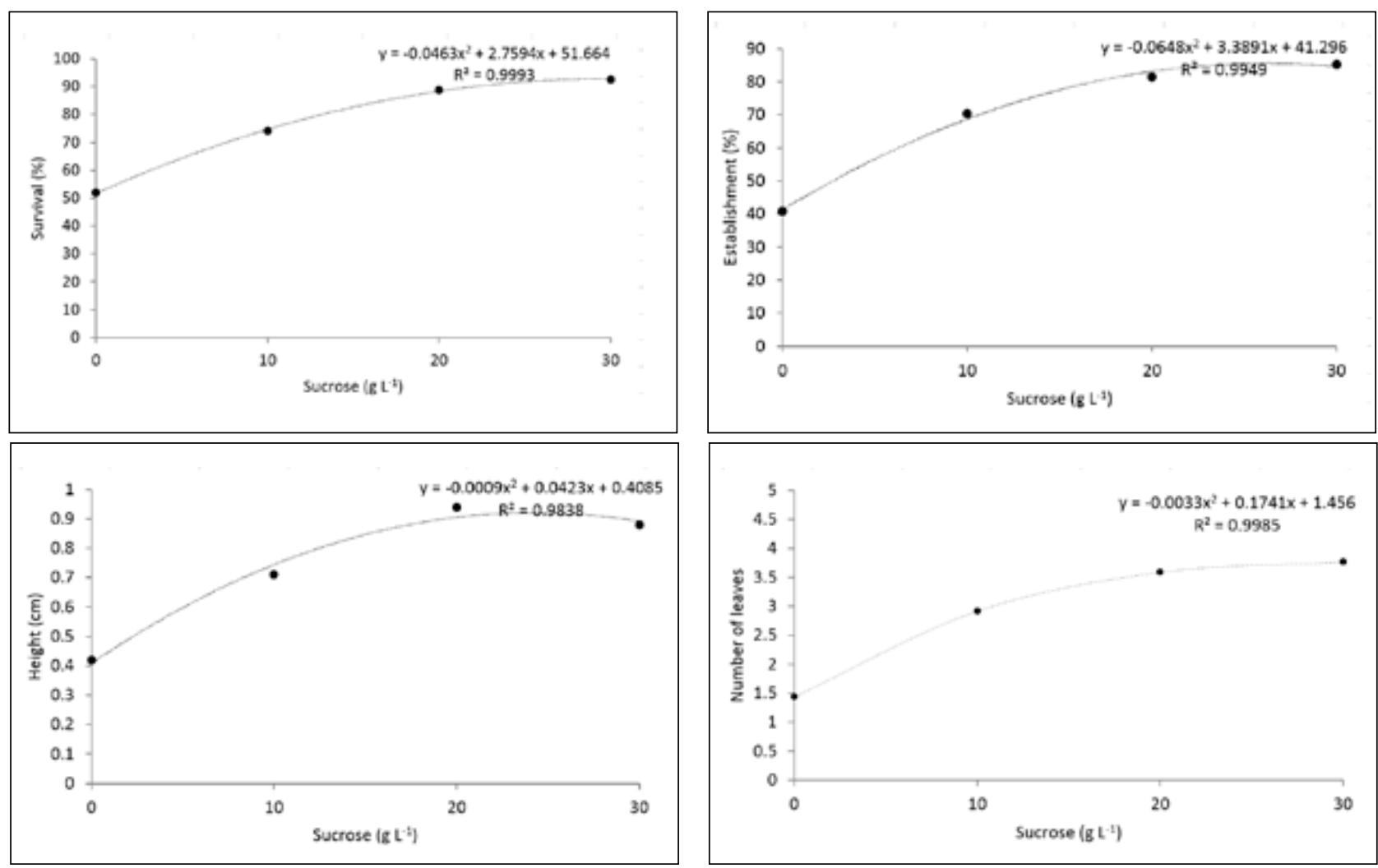

Figure 3. Means of survival and establishment (expressed as a percentage), height (cm) and number of leaves in Luehea divaricata Mart. \& Zucc. shoots depending on the sucrose concentration used during in vitro culture (30 days) in WPM/2 nutritive medium, regardless of the substrate used later in the second acclimatization period after five days in the culture room with the uncovered plastic cups. Santa Maria, RS, UFSM, 2017.

There was a significant effect of sucrose concentrations ( $p=0.0017, p=0.0017$ respectively), with an equation adjustment for both variables and with MTE estimated at $23.5 \mathrm{~g} \mathrm{~L}^{-1}$ and $26.4 \mathrm{~g} \mathrm{~L}^{-1}$ respectively (Figure 3) for the height $(\mathrm{IV}=8.18)$ and number of leaves (IV = 15.39). There was also a significant effect of height and number of leaves in relation to the tested substrates $(p=0.0156, p=0.0031$, respectively) (Table 1), but not on the interaction between the two main factors ( $p=0.2663 ; p=0.1374$, respectively).

During the second in vitro acclimatization period, it was generally observed that the best means of survival, establishment, height and number of leaves were again obtained by the shoots that had been cultivated in vitro in the presence of sucrose. This result indicates the importance of this component for in vitro development, and consequently for the acclimatization of the vegetal tissues cultivated under these conditions, as verified in the present study.

Studies with Malus domestica (apple tree) showed that the survival of the plants between seven and 21 days of acclimatization fell to $85 \%$ due to the stress of transferring the plants from the laboratory to the greenhouse. In addition, a drastic fall in plant survival occurs around two weeks after beginning the acclimatization due to the low efficiency in the exchange of the heterotrophic to the autotrophic metabolism (Hoffmann et al., 2001).

\subsection{Third acclimatization period, ex vitro (30 days in a greenhouse)}

In the third acclimatization period, there was a significant effect of the different sucrose concentrations ( $p=0.0005$, $p=0.0149$, respectively) for survival $(\mathrm{IV}=10.79)$ and establishment (IV $=11.56)$, but not for the tested substrates ( $p=0.3005, p=0.3326$, respectively), nor for the interaction between the two main factors $(p=0.2499, p=0.1127$, respectively). A second-degree equation was adjusted for both variables with the MTE estimated at $27.3 \mathrm{~g} \mathrm{~L}^{-1}$ and $24.3 \mathrm{~g} \mathrm{~L}^{-1}$, respectively (Figure 4). 

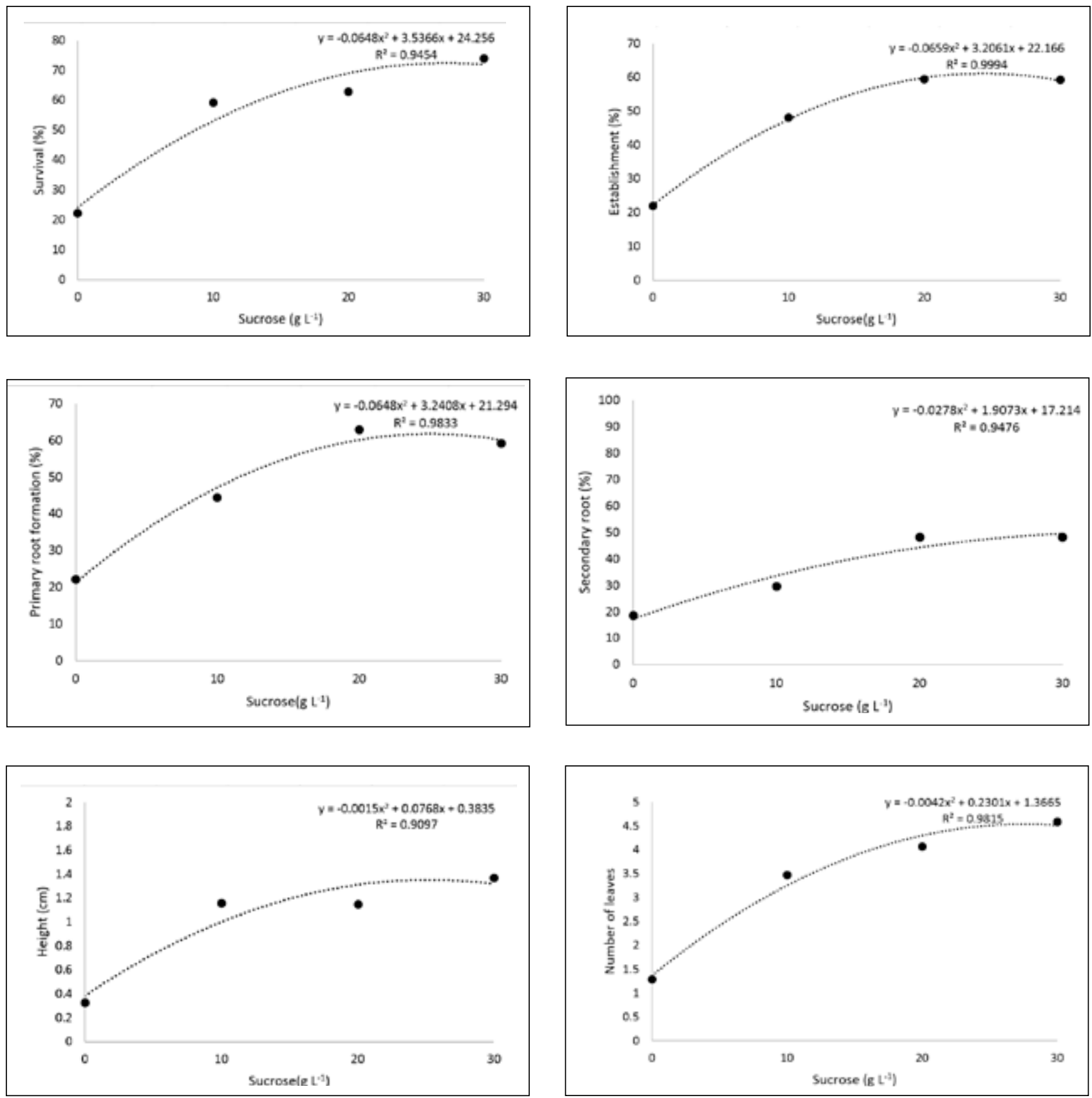

Figure 4. Means of survival, establishment, primary and secondary root formation (expressed as a percentage), height (cm) and number of leaves in Luehea divaricata Mart. \& Zucc. shoots depending on sucrose concentration used during in vitro culture (30 days) in WPM/2 nutritive medium, regardless of the substrate used later in the third acclimatization period after 30 days in the greenhouse. Santa Maria, RS, UFSM, 2017.

In this acclimatization step, plants that were in sucrosecontaining nutritive medium before passing to the substrates generally (and again) developed more satisfactorily than those in the medium in the absence of sucrose. However, it is possible to reduce sucrose concentrations in the nutritive medium without losses in survival, establishment, root formation, height and number of leaves. Reducing the sucrose amount in the medium promotes benefits to plants, not only by promoting the photoautotrophic condition in vitro, but also by reducing plant loss by biological contamination in the culture medium (Kozai, 1991).

There was a significant effect of the sucrose concentrations $(p=0.0082)$ for the primary root $(\mathrm{IV}=11.49)$, but not of the substrate ( $p=0.2023)$ nor of the interaction between the main factors $(p=0.1644)$, with a second-degree equation being adjusted with MTE estimated at $25 \mathrm{~g} \mathrm{~L}^{-1}$ (Figure 4). 
On the other hand, there was a significant sucrose effect ( $p=0.0283, p=0.0015$ and $p=0.0025$ ) and of the substrate ( $p=0.0002, p=0.0110$ and $p=0.0076$, respectively) (Table 1 , Figure 4), but not of the interaction between them ( $p=0.0819$, $p=0.0757$ and $p=0.0549$, respectively) in relation to the secondary root $(\mathrm{IV}=11.07)$, height $(\mathrm{IV}=15.71)$ and leaf number $(I V=23.92)$. For the variables secondary root, height and number of leaves, a second-degree equation was adjusted in relation to sucrose concentrations, with the MTE estimated at $34.3 \mathrm{~g} \mathrm{~L}^{-1}, 25.6 \mathrm{~g} \mathrm{~L}^{-1}$ and $27.4 \mathrm{~g} \mathrm{~L}^{-1}$ respectively.

A small reduction in the number of surviving plants during the acclimatization may occur due to their transference from the culture room to the greenhouse. This fact is usually due to the change in the environmental conditions that the plants were subjected to in the culture room, mainly in relation to the temperature which is strictly controlled. In the greenhouse, high temperatures associated with high relative air humidity favor a proliferation of fungi and bacteria which can cause the death of some plants. Allied to this condition, the fragility of the tissues which are not very lignified and do not have a cuticular layer leaves the plants vulnerable to an invasion by saprophytic microorganisms and pathogen attack (Fermino \& Scherwinski-Pereira, 2012; Grattapaglia \& Machado, 1998).

MecPlant and $\mathrm{H}$-decker substrates yielded the best results for secondary root formation (Table 1), as well as the height and number of leaves in the first period, probably because they gave plants a greater reserve of water and air. On the other hand, the ex vitro rooting of Tectona grandis (teak) after 30 days occurred in both vermiculite (85\%) and Plantmax substrates (95\%), which resulted in high averages and the absence of callus formation on shoot bases. In addition, acclimatization on both substrates was maximal (Fermino et al., 2011).

In order to optimize the micropropagation process, rooting can be performed under in vitro culture conditions, but in containers with substrate and not in flasks containing nutritive medium. This strategy is desirable from the technical point of view to improve the root system quality with a greater number of secondary roots without the formation of calli, which often hinder the vascular connection between stem and root (Grattapaglia \& Machado, 1998; Vieira et al., 2007), as well as from the economic point of view, representing a considerable reduction in labor and infrastructure costs, eliminating the necessity to apply for specific nutritive medium.

In addition, the micropropagation acclimatization stage is quite critical, since in vitro rooted plants move from a situation of reduced transpiration flow to an environment that demands an increase in the transpiration rate, making them susceptible to water stress. For this reason, acclimatization is carried out in a gradual and careful manner, and the success of this phase depends on the quality of the shoots obtained in the rooting phase, the response of the species and also the acclimatization structure, which includes temperature, luminosity, moisture, substrate and nutrients (Oliveira et al., 2013; Xavier et al., 2009).

\section{CONCLUSION}

Sucrose at $20 \mathrm{~g} \mathrm{~L}^{-1}$ is more efficient for the in vitro formation of primary roots and leaves in Luehea divaricata; however, the increase to $30 \mathrm{~g} \mathrm{~L}^{-1}$ favors survival, establishment, height and secondary root formation. MecPlant or $\mathrm{H}$-decker substrates may be used in in vitro and ex vitro acclimatization.

\section{ACKNOWLEDGEMENTS}

The authors thank Universidade Federal de Santa Maria (UFSM) for the structure and support for performing experiments.

\section{SUBMISSION STATUS}

Received: 1 June 2017

Accepted: 14 Aug. 2018

Associate editor: Evânia Galvão Mendonça

\section{CORRESPONDENCE TO}

\section{Lia Rejane Silveira Reiniger}

Universidade Federal de Santa Maria, Av. Roraima, 1000, CEP 97105-900, Santa Maria, RS, Brasil

e-mail: liarsr@ufsm.br

\section{FINANCIAL SUPPORT}

Coordenação de Aperfeiçoamento de Pessoal de Nível Superior (Capes) and Conselho Nacional de Desenvolvimento Científico e Tecnológico (CNPq)

\section{REFERENCES}

Bandeira FS, Xavier A, Otoni WC, Lani ERG. Aclimatização ex vitro de plantas propagadas pela enxertia in vitro de clones de Eucalyptus urophylla $\times$ E. grandis. Revista Árvore 2007; 31(5): 773-781. 10.1590/S0100-67622007000500001

Carvalho DC, Silva ALL, Schuck MR, Purcino M, Tanno GN, Biasi LA. Fox grape cv. Bordô (Vitis labrusca L.) and grapevine cv. Chardonnay (Vitis vinifera L.) cultivated in vitro under different carbohydrates, amino acids and 6-Benzylaminopurine levels. Brazilian Archives of Biology and Technology 2013; 56(2): 191-201. 10.1590/S1516-89132013000200004

Carvalho, PER. Espécies arbóreas brasileiras. Brasília, DF: Embrapa; 2003. 
Curti AR, Reiniger LRS. Formação in vitro de raízes em canafístula: o efeito de diferentes meios de cultivo. Ciência Rural 2014; 44(2): 314-320. 10.1590/S0103-84782014000200019

Fermino PCP Jr, Raposo A, Scherwinski-Pereira JE. Enraizamento ex vitro e aclimatização de plantas micropropagadas de Tectona grandis. Floresta 2011; 41(1): 79-86. 10.5380/rf.v41i1.21184

Fermino PCP Jr, Scherwinski-Pereira JE. Germinação e propagação in vitro de cerejeira (Amburana acreana (Ducke) A.C. Smith Fabaceae). Ciência Florestal 2012; 22(1): 1-9. 10.5902/198050985074

Fernandes DA, Souza RS, Costa RB. Cultivo in vitro de teca (Tectona grandis L.f.): uma revisão. Revista de Agricultura 2011; 86(1): 32-46.

Ferreira DF. Sisvar: a guide for its bootstrap procedures in multiple comparisons. Ciência e Agrotecnologia 2014; 38(2): 109-112. 10.1590/S1413-70542014000200001

Galdiano RF Jr, Mantovani C, Cassano AO, Lemos EGM. Desenvolvimento inicial e crescimento in vitro de Cattleya violacea (Kunth) Rolfe em diferentes concentrações de sacarose. Acta Amazonica 2013; 43(2): 127-134. 10.1590/S0044-59672013000200001

Girardi CG, Pescador R. Aclimatação de gengibre (Zingiber officinale Roscoe) e a relação com carboidratos endógenos. Revista Brasileira Plantas Medicinais 2010; 12(1): 62-72. 10.1590/S1516-05722010000100010

Grattapaglia D, Machado MA. Micropropagação. In: Torres AC, Caldas LS, Buso JA. Cultura de tecidos e transformação genética de plantas. Brasília, DF: Embrapa; 1998. v. 1. p. 183-260.

Hoffmann A, Pasqual M, Chalfun NNJ, Vieira SSN. Substratos na indução e desenvolvimento in vitro de raízes em dois portaenxertos de macieira. Pesquisa Agropecuária Brasileira 2001; 36(11): 1371-1379. 10.1590/S0100-204X2001001100007

Kozai T. Micropropagation under photoautotrophic conditions. In: Debergh P, Zimmerman RH, editors. Micropropagation technology and application. Dordrecht: Springer; 1991. p. 447-469.

Lemes CSR, Sorgato JC, Soares JS, Rosa YBCJ. Meios de cultivo e sacarose no crescimento inicial in vitro de Miltonia flavescens. Ciência Rural 2016; 46(3): 499-505. 10.1590/0103-8478cr20150368

Lloyd G, McCown B. Commercially feasible micropropagation of mountain laurel, Kalmia latifolia, by use of shoot tip culture. Combined Proceedings International Plant Propagators' Society 1980; 30: 421-427.
Lorenzi H. Árvores brasileiras: manual de identificação e cultivo de plantas arbóreas nativas do Brasil. Nova Odessa: Plantarum; 2008. v. 1.

Maldaner J, Nicoloso FT, Santos ES, Fagundes CK, Flores R, Jucoski $\mathrm{GO}$ et al. Crescimento de plântulas de Pfaffia glomerata (Spreng.) Pedersen cultivadas in vitro sob dois níveis de nitrogênio e sacarose, durante seis subculturas sucessivas e aclimatização. Ciência Rural 2007; 37(1): 133-140. 10.1590/S0103-84782007000100021

Murashige T, Skoog F. A revised medium for rapid growth and bio assays with tobacco tissue cultures. Physiologia Plantarum 1962; 15(3): 473-497. 10.1111/j.1399-3054.1962.tb08052.x

Oliveira LS, Dias PC, Brondani GE. Micropropagação de espécies florestais brasileiras. Pesquisa Florestal Brasileira 2013; 33(76): 439-453.

Oliveira Y, Pinto F, Silva ALL, Guedes I, Biasi LA, Quoirin M. An efficient protocol for micropropagation of Melaleuca alternifolia Cheel. In Vitro Cellular and Developmental Biology: Plant 2010; 46(2): 192-197. 10.1007/s11627-010-9287-6

Pimentel-Gomes F. Curso de estatística experimental. 15th ed. Piracicaba: FEALQ; 2009.

Schuch M, Damiani CR. Diferentes substratos e ambientes no enraizamento in vitro de mirtilo. Ciência Rural 2009; 39(2): 563-566. 10.1590/S0103-84782009000200040

Souza AV, Pereira AMS. Enraizamento de plantas cultivadas in vitro. Revista Brasileira de Plantas Medicinais 2007; 9(4): 103-117.

Taiz L, Zeiger E, Møller IM, Murphy A. Fisiologia vegetal. 3rd ed. Porto Alegre: Artmed; 2004.

Vasconcelos JM, Leão JRA, Raposo A, Fermino PCP Jr. Sistemas de cultivo in vitro e aclimatização de Aechmea setigera Mart. ex Schult. \& Schult. f. (Bromeliaceae). Scientia Agraria Paranaensis 2015; 14(4): 240-246. 10.18188/1983-1471/sap.v14n4p240-246

Vieira RL, Leite GB, Wamser AF. Efeito de substratos porosos no enraizamento in vitro do porta-enxerto de macieira M-9 (Malus pumilla). Revista Brasileira de Fruticultura 2007; 29(1): 128-132. 10.1590/S0100-29452007000100028

Xavier A, Wendling I, Silva RL. Silvicultura clonal: princípios e técnicas. Viçosa: Editora UFV; 2009. 